\title{
機台振動抑制を考慮した GAによるロバスト高速·高精度位置決め制御系設計
}

\author{
正 員 伊藤 和晃* 学生員 永田 良** \\ 正員 岩崎 誠** 正 員 松井 信行**
}

\author{
GA-Based Autonomous Design of Robust Fast and Precise Positioning \\ Considering Machine Stand Vibration Suppression \\ Kazuaki Ito*, Member, Ryo Nagata**, Student Member, Makoto Iwasaki**, Member, \\ Nobuyuki Matsui**, Member
}

This paper presents a novel Genetic Algorithm (GA)-based autonomous compensator design and position command shaping considering the stand vibration suppression for the fast-response and high-precision positioning of mechatronic systems. The positioning system is mainly composed of a robust 2-degrees-of-freedom (2DOF) controller based on the coprime factorization description. The feedback compensator based on $H_{\infty}$ design framework in the 2DOF controller ensures the robustness against the variations of resonant vibration mode. The feedforward compensator and position command, on the other hand, can be autonomously designed by the optimization capability of GA, in order to achieve the desired positioning performance and to suppress the machine stand vibration. The effectiveness of the proposed optimal design has been verified by experiments using a table drive system with ball screw.

キーワード：機台振動, 位置指令整形, 2 自由度制御, 高速·高精度位置決め, 遺伝的アルゴリズム, 自律設計

Keywords: machine stand vibration, position command shaping, 2-degrees-of-freedom control, fast-response and high-precision positioning, genetic algorithm, autonomous design

\section{1. まえがき}

工作機械や電子部品加工機などのメカトロニクス機器で は，製品の高効率生産や品質向上のため，高速かつ高精度 な位置/速度制御の実現か救められ,さらに, 製品の多樣化 や製造コスト低減に対応するため, 装置全体の小型·軽量 化も推し進められている。この場合, 機構系の低剛性要素 に起因する共振振動によって制御性能が低下する場合が多 く, 共振振動抑制 (以下, 制振) 機能を備えた高性能サ一 ボコントローラの実現が必要不可欠である。

ボールねじ駆動によるテーブルシステムを例に挙げれば， ボールねじ機構部でのねじれ振動や摩擦等の非線形要素, 付帯設備からの外乱等の影響によって, テーブル位置決め

\footnotetext{
* 豊田工業高等専門学校

干 471-8525 豊田市栄生町 2-1

Toyota National College of Technology

2-1, Eisei-cho, Toyota 471-8525

** 名古屋工業大学大学院工学研究科

干 466-8555 名古屋市昭和区御器所町

Nagoya Institute of Technology

Gokiso-cho, Showa-ku, Nagoya 466-8555
}

制御性能が低下する。さらに，装置の小型·軽量化に伴う 機台の低剛性化が , テーブル推力の反力によって装置全体 を振動させる機台振動という新たな問題を引き起こしてい $る^{(1)(2)}$ 。

これら機構振動の発生要因は制御対象のメカニズムに依 るところが大きいが, 駆動条件や機械パラメータ変動によっ て周波数変動を伴う場合と伴わない場合に大きく分類でき る。周波数変動を伴う場合に対しては, システムのロバス 卜安定性を視野に入れたフィードバック (以下，FB）での 制振制御が必要で, $H_{\infty}$ 制御に代表されるロバスト制御理 論の適用が有望である ${ }^{(3)}(4) 。 一$ 方, 周波数変動を伴わない 場合に対しては,フィードフォワード補償器（以下，FF 補 償器）を位置指令に対するフィルタとして適用し, 目標值追 従性能の向上を图ることや，指令生成時に位置指令に含有 の特定周波数成分を除去して, 制振制御を実現することが

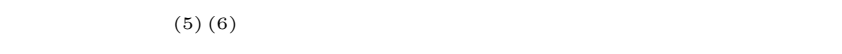
に設計自由度があるという考え方に基づくものであり，制 御処理の計算負荷軽減という点からも極めて有用である ${ }^{(7)}$ 。 従って, FF 補償器と位置指令を積極的に連携させて設計 することは, 実用面からも肝要であり, 弚の場合, 複数の 
駆動条件下でも常に要求仕樣を満足し，かつ現実的な設計 処理時間で FF 補償器と位置指令を最適化できる設計ツー ルの実現か望まれる。

本研究は, 機台上に設置されたボールねじ駆動テーブル システムに対して構成した 2 自由度位置決め制御系の FF 補償器と位置指令を, 遺伝的アルゴリズム ${ }^{(8)}$ (以下，GA) により最適設計する ${ }^{(9)}$ 。光こでは, システムのロバスト安 定化を目的とした $H_{\infty}$ 制御による FB 補償器の適用を前提 に，機台振動や負荷外乱に起因するテーブル制振制御を目 指す位置指令生成と，高速・高精度な目標值追従性を実現 する既約分解表現に基づく $\mathrm{FF}$ 補償器を，GA により最適 化する。

筆者らは既に，主に 2 慣性共振系の制振制御を対象に，H 補償器設計や 2 自由度補償器設計に GA による最適化手法 を適用し，兴の基本的アルゴリズムを検証してきた ${ }^{(10) \sim(12) 。 ~}$ 本論文は，これら一連の研究の延長線上に位置し，実製品 の制御系設計への展開，新たに提起された機台振動問題へ の対応を試みるものであり，次世代設計ツールの提案を行 うものである。

提案設計手法は，機台上に設置されたボールねじ駆動に よる供試テーブルシステムに適用され，機台振動抑制とテー ブル位置決め制御に対する実験検証によって，光の有効性 を明らかにしている。

\section{2. 機台振動を考慮した高速・高精度位置決め制御系}

〈2: 1〉 ボールねじ駆動テーブルシステム＼cjkstart図 1 は, 本 研究で対象とする機台上に設置されたボールねじ駆動テー ブルシステムの概観図である。ボールねじとモータは減速 機構を介して連結され，テーブルには重量可変の付帯設備 が負荷として搭載される。ボールねじ機構部での共振振動 (以下, ボールねじ共振) は, 負荷重量やボールねじに対す るテーブル位置 (以下, テーブル初期位置) に応じて周波 数が $80 \mathrm{~Hz}$ から $130 \mathrm{~Hz}$ の範囲で変動する。一方, 本シス テムでは, 負荷からのトルク外乱により発生する共振振動 と機台振動の固有周波数は, 負荷重量, テーブル移動距離, テーブル初期位置等の駆動条件に依らず $33 \mathrm{~Hz}$ と $29 \mathrm{~Hz}$ で 一定である。

一般には, 機台振動がテーブル位置決め制御性能を低下 させる場合も多いが , 本システムの機台振動に起因するテー ブル振動振幅は要求位置決め精度に比べて十分小さく，光 の結果モ一タ位置情報に観測量として重畳する機台振動も 極めて小さい。従って，制御系設計問題を簡略化する意味 で，ここでは機台振動による位置決め制御性能の低下は生 じないものと問題設定する。しかし，周辺作業環境への励 起振動を抑制するため, 機台振動に対する制振制御が必要 であることには変わりはない。

図 2 は図 1 のシステムに対するブロック線図†であり，

†前述の通り，本システムでは機台振動は位置決め制御性能に影響 を与えないことから, 機台位置 $x_{B}$ がモ一夕位置 $\theta_{M}$ やテーブル位置 $x_{A}$ に対してフィードバックされていないことに留意されたい

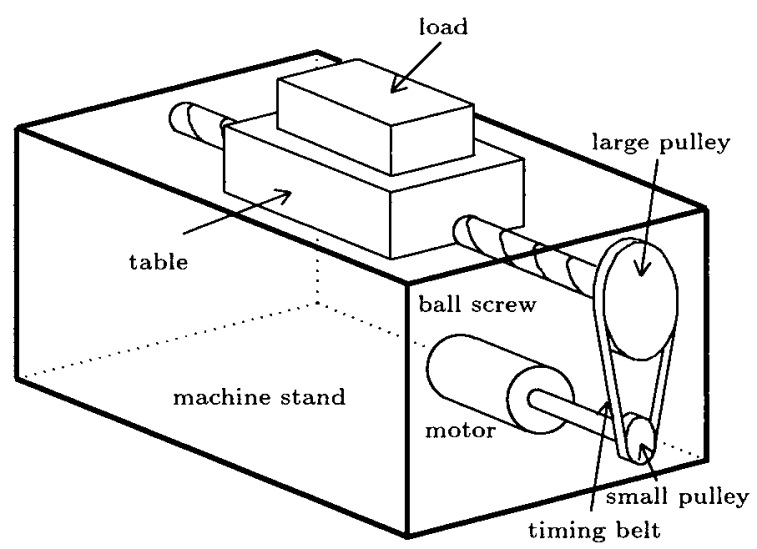

図 1 ボールねじ駆動テーブルシステム概観図

Fig. 1. Structural configuration of table drive system with machine stand.

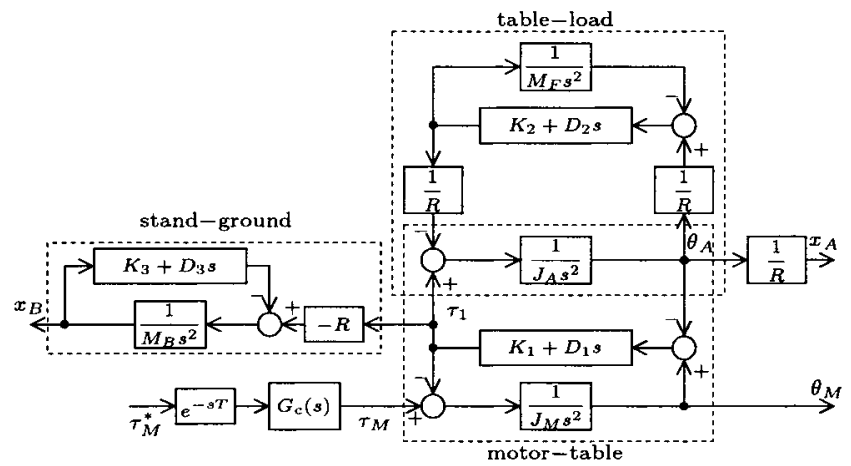

図 2 ボールねじ駆動テーブルシステムブロック線図

Fig. 2. Block diagram of table drive system.

モータ・テーブル間で発生するボールねじ機構部での共振 振動，負荷からのトルク外乱に起因するテーブルの共振振 動, モータ・テーブル間のねじれ誤差に起因する機台振動 に対する運動方程式から導出されるものである。図中の変 数·定数は, $\tau_{M}^{*}$; モ一タトルク指令, $\tau_{M}$; モータトルク， $\theta_{M}$; モ一夕位置, $\theta_{A}$; モ一夕軸換算のテーブル位置, $x_{A}$; テーブル位置, $x_{B}$; 機台位置, $J_{M}$; モータ慣性モーメン 卜， $J_{A}$; テーブル質量をモータ軸換算した慣性モーメント， $M_{F}$; 負荷質量 , $M_{B}$; 機台質量 , $K_{1} \sim K_{3}$; ばね定数 , $D_{1} \sim$ $D_{3}$; ダンピング係数,$R\left(=\theta_{A} / x_{A}\right)$; モ一タ軸へ換算す る際の変換係数であり, モ一タの電流制御系に対応する伝 達関数を $G_{c}(s)$, ディジタル制御での演算処理時間やシス テムの遅れ要素に起因する無駄時間を $T$ としている。ここ で, 本システムの制御入力は $\tau_{M}^{*}$ で, 観測量は $\theta_{M}$ である。

この場合 , テーブル初期位置に応じたボールねじ岡性 (ば ね定数 $\left.K_{1}\right)$ の変化に伴い, ボールねじ共振周波数は変動す る。また, テーブル・負荷間の共振周波数を負荷重量によ らず一定とするため, $M_{F}$ に応じてばね定数 $K_{2}$ を変化さ せている。

本システムの位置決め仕樣は，位置制御サンプリング時間 $T_{S}$ (=0.5 ms) の下, 上位コントローラからのテーブル移動 距離指令に対して, point to point で目標位置の $\pm 120 \mu \mathrm{m}$ 


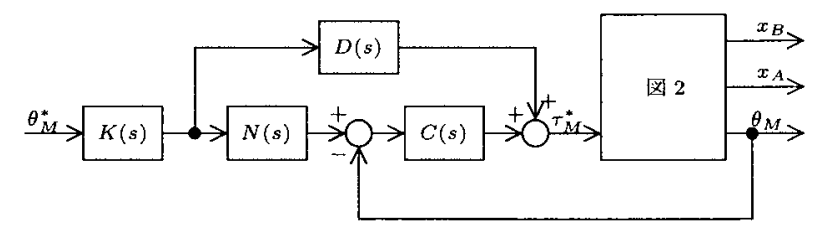

图 32 自由度位置決め制御系ブロック線図

Fig. 3. Block diagram of 2-degrees-of-freedom positioning system.

以内に整定することである。なお，テーブル移動距離には $17.4 \mathrm{~mm}, 32 \mathrm{~mm}, 48 \mathrm{~mm}$ があり，要求整定時間は，位置

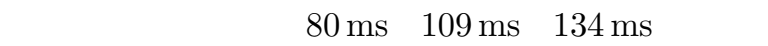

〈2. 2〉 2 自由度位置決め制御系設計指針本制御シス テムでは, テーブル位置に対する高速・高精度な追従特性 の実現と, プラント変動に対するロバスト安定性の確保を 目的に，2 自由度制御系を構筑する。図 3 は，図 2 のシステ ムに対して構成した位置決め制御系ブロック図である。图 中, $C(s)$ は $\mathrm{FB}$ 補償器, $D(s), N(s), K(s)$ は光れ羿れ $\mathrm{FF}$ 補償器， $\theta_{M}^{*}$ はモータ位置指令を示す。ここでは, $\mathrm{FF} / \mathrm{FB}$

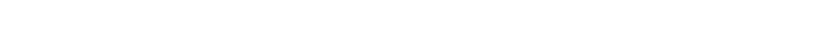
に基づき設計する。

(1) ボールねじ共振は, モータ位置制御開ループ特性のゲ イン交差周波数付近に存在し, 周波数変動も生ずるの で, システムの安定性に直接影響を与える。光こで， ボールねじ共振に対する安定化及び周波数变動に対す るロバスト安定化を実現すべく， $H_{\infty}$ 制御による FB 補償器設計を実施する。

（2）負荷からのトルク外乱に起因する共振振動を抑制し , $x_{A}$ の $\theta_{M}^{*}$ に対する目標值追従性能を向上させるため, $\tau_{M}$ から $\theta_{M}$ までの伝達特性を既約分解して得られる $D(s)$ と $N(s)$ に， $\tau_{M}$ から $\theta_{A}$ までの伝達特性を含ま せて，プラントモデルベースの FF 補償を実施する。

(3) 機台振動周波数は駆動条件によらず一定であるため, 位置指令から機台振動周波数付近の周波数成分を除去 する目的で， $K(s)$ にはノッチフィルタを採用する。

(4) $\theta_{M}^{*}$ は変形正弦力 ム曲線 ${ }^{(13)}$ を基に生成し, 弚の設計パ ラメータはテーブル位置及び機台の振動抑制を実現で きるよう最適化する。

（5）以上の設計指針に対して，所望の位置決め制御特性と 機台振動抑制を実現すべく，GA により FF 補償器と 位置指令の各設計パラメータを最適設計する。光の際， 負荷重量 , テーブル移動距離 , テーブル初期位置に対 する複数の駆動条件下でも制御仕樣を満足させること を目指す。ただし，移動距離の変更に伴うテーブル駆 動モードは多数存在し, 光れら全てに対して FF 補償 器の最適化を実施することは設計負荷が膨大て現実的 ではない。従って , 本システムで代表的な $17.4 \mathrm{~mm}$ 移 動時のみ FF 補償器の最適設計を実施し, 弚の他の移 動距離に対しては, モー夕位置指令のみの最適設計と する。

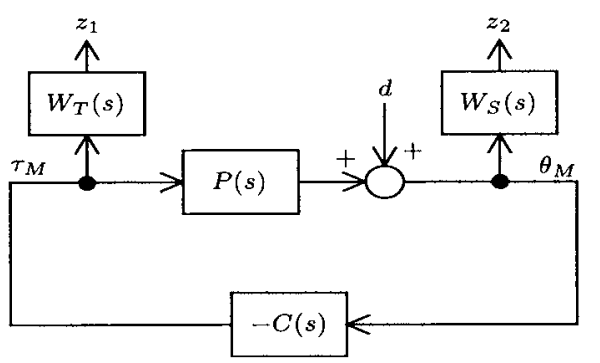

図 4 一般化プラント

Fig. 4. Generalized plant.
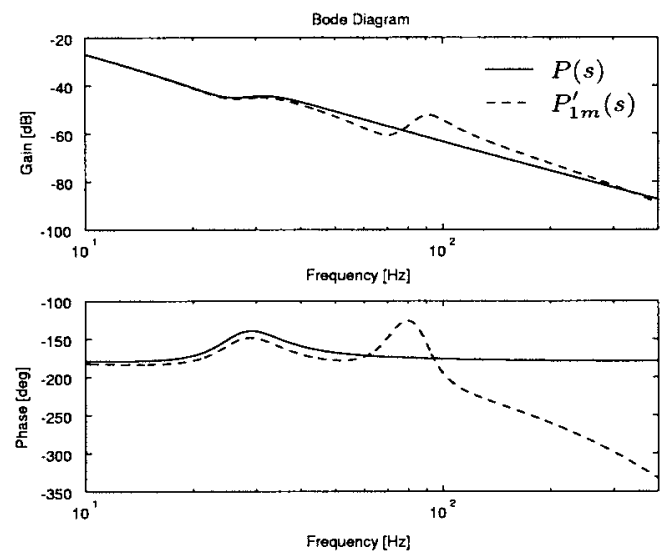

図 $5 P(s)$ の周波数特性ボード線図

Fig. 5. Bode characteristics of nominal plant dynamics $P(s)$.

\section{2 自由度位置決め制御系設計}

〈3. 1 $\boldsymbol{H}_{\infty}$ 制御による FB 補償器設計 $H_{\infty}$ 制御に よる FB 補償器設計では, 図 4 の一般化プラントを用いて 混合感度問題による補償器設計を実施する。ここで, $P(s)$ はモータトルク $\tau_{M}$ からモータ位置 $\theta_{M}$ までのノミナルプ ラントモデル, $W_{T}(s)$ と $W_{S}(s)$ は, 光れぞれシステムの 相補感度関数と感度関数に対する重み関数である。また,$d$ は外生信号， $z_{1}$ 及び $z_{2}$ は制御量である。

負荷重量とテーブル初期位置に応じてボールねじ共振周 波数は異なるので, 特定条件下でのプラントモデルを $P(s)$ に用いると，他の条件下ではボールねじ共振周波数付近で モデル化誤差が大きくなる。光こで, $P(s)$ が負荷からの外 乱による $33 \mathrm{~Hz}$ の共振特性のみを有するよう，負荷重量が 最大でテーブルがボールねじ中央に位置する場合のプラン 卜モデル $P_{1 m}^{\prime}(s)$ をもとに，モータ・テーブル間を剛体系 として低次元化したものを $P(s)$ に用いる。図 5 中の実線 は $P(s)$ の周波数特性であり, 破線は $P_{1 m}^{\prime}(s)$ である。图か ら，P $(s)$ は $33 \mathrm{~Hz}$ の共振特性のみを有していることが分か る。なお，負荷重量とテーブル位置に応じたプラントモデ ル $P_{i j}^{\prime}(s)$ は, $P(s)$ と加法変動のモデル化誤差 $\Delta_{i j}$ を用い て (1) 式で表される。

$$
P_{i j}^{\prime}(s)=P(s)+\Delta_{i j}
$$




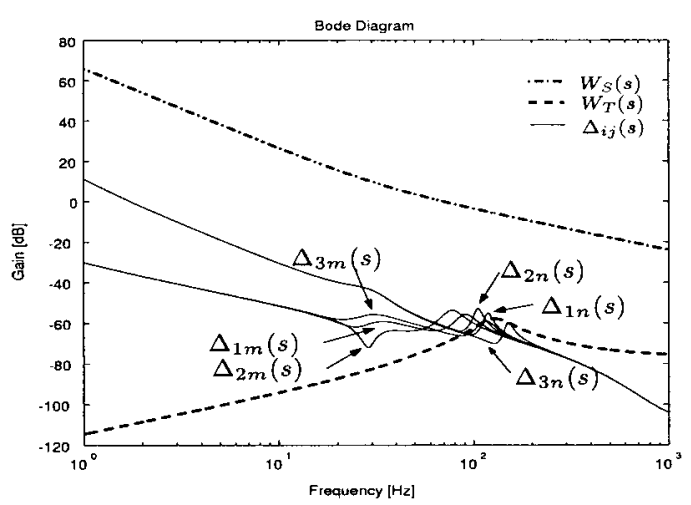

図 6 重み関数と加法変動 $\Delta$

Fig. 6. Weighting functions and additive perturbations.

ここで, 添え字 $i$ はテーブル初期位置条件 $(1$ ；ボールねじ 中央， $2 ;$ モ一タに対して遠端，3;近端)，j (負荷重量条

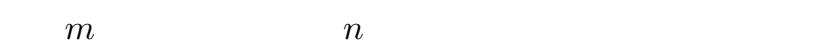
合の $\Delta_{i j}$ の周波数特性ゲイン線図を図 6 に示す。

重み関数の設計に当たっては, $W_{T}(s)$ はシステムのロバ ス卜安定性を規定する観点から， $\Delta_{i j}$ に比べて全周波数域 で高ゲインの $W_{T}(s)$ が望まれるが，乥の場合，十分な安 定性と引き換えにシステムの高応答化は困難となる。本シ ステムの場合 , モデル化誤差の多くはボールねじ共振の周 波数变動に起因するので, ボールねじ共振周波数付近での 位相余有を改善することによって，モデル化誤差に対する ロバスト安定化は実現できる。弚こで， $\Delta_{i j}$ に比へて全周 波数域で高ゲインではないものの, $130 \mathrm{~Hz}$ 付近でゲインの ピークを持つよう $W_{T}(s)$ を設計した。

一方，外乱や低周波数域でのモデル化誤差に対する低感 度化を実現するため， $W_{S}(s)$ は低周波数域で積分特性を有 する構造とした。図 6 に $W_{T}(s)$ と $W_{S}(s)$ の周波数特性ゲ イン線図を示す。

〈3. 2〉機台振動抑制を考慮した FF 補償器 本位置 決めシステムは，モータ位置情報を用いたセミクローズド 方式なので, テーブル位置 $\theta_{A}$ のモータトルク $\tau_{M}$ に対す る伝達関数 $\theta_{A} / \tau_{M}$ を用いて，(1) 式の低次元化されたプラ ントモデル $P(s)$ を次式のように既約分解する。

$$
P(s)=\frac{N(s)}{D(s)}, N(s)=\frac{N_{M}(s)}{N_{A}(s) F(s)}, D(s)=\frac{D_{M}(s)}{N_{A}(s) F(s)}
$$

ここで, $N_{M}(s), D_{M}(s)$ は，光れ光れ $P(s)$ の分子，分母 多項式であり， $N_{A}(s)$ は $\theta_{A} / \tau_{M}$ の分子多項式である。 の場合， $D_{M}(s)$ は 4 次多項式， $N_{A}(s)$ は 2 次多項式であ るので，次式で示す 2 次多項式 $F(s)$ を付加して $D(s)$ をプ ロパな伝達関数とする。

$F(s)=\frac{1}{\omega_{f}^{2}} s^{2}+\frac{2 \zeta_{f}}{\omega_{f}} s+1$, ここで, $\omega_{f}=2 \pi f_{f} \cdots$

この結果， $D(s)$ は, プラントが有する $33 \mathrm{~Hz}$ の共振特 性を打ち消すフィードフォワードトルクを生成するフィル

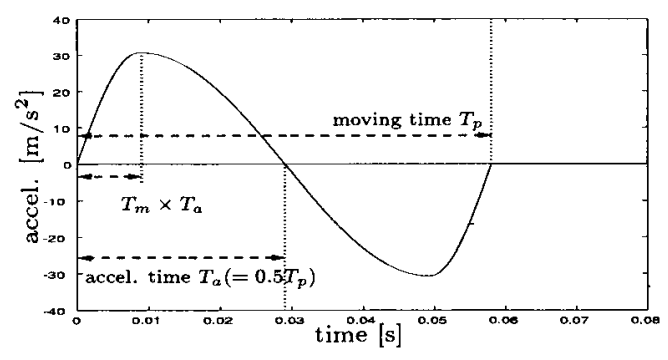

図 7 変形正弦力么曲線に基づく加速度波形

Fig. 7. Acceleration waveform based on modified sine cam shape.

タ, $N(s)$ は, テーブルが位置指令に速やかに追従するよ う，フィードバック系に対して位置指令を補正するフィル タとなる。

一方， $K(s)$ は周波数変動のない機台振動抑制を主目的と して , 次式のノッチフィルタを採用する。

$$
\begin{aligned}
& K(s)=\frac{\omega_{d}^{2}}{\omega_{n}^{2}} \cdot \frac{s^{2}+2 \zeta_{n} \omega_{n} s+\omega_{n}^{2}}{s^{2}+2 \zeta_{d} \omega_{d} s+\omega_{d}^{2}} . \\
& \text { ここで, } \quad \omega_{n}=2 \pi f_{n}, \quad \omega_{d}=2 \pi f_{d}
\end{aligned}
$$

システムへの入カエネルギーを主に規定するのは位置指令 であるので, 位置決め性能と機台振動抑制性能の向上には 位置指令設計との連携が必要不可欠である。従って， $K(s)$ の分母多項式と分子多項式の固有角周波数 $\omega_{d}, \omega_{n}$ を個別 に設定することで設計自由度を持たせ，次項の位置指令設 計との組み合わせによって位置決め制御性能と機台振動抑 制性能の向上を図る。

〈3. 3〉変形正弦力ム曲線に基づくモ一夕位置指令 位 置指令には, 图 7 に示す变形正弦力 厶曲線に基づく加速度 波形の 2 階積分值を用いる。图中，移動時間 $T_{p}$ と加速時 間 $T_{a}$ に対する最高加速度到達時間の割合 $T_{m}$ が位置指令 生成パラメータであり， $T_{p}$ と $T_{m}$ に応じて位置指令の周波 数成分と加速ピーク値は変化する。なお， $T_{m}$ の設定範囲 は 0 から 0.5 である。

〈3. 4〉 GA による FF 補償器と位置指令の最適設計処 理概要图 8 は, $\mathrm{GA}$ による $\mathrm{FF}$ 補償器と位置指令の最 適設計概要図である。プラントモデルと 2 自由度補償器で 構成されるシステム数学モデルに対し, 変形正弦力ム曲線 に基づく位置指令 $\theta_{M}^{*}$ を印加し, テーブル位置波形 $x_{A}$ と 機台加速度波形 $\ddot{x}_{B}$ を計算する。乥して, 得られた $x_{A}$ と $\ddot{x}_{B}$ の時系列データに対して, 後述の評価関数によって遺 伝的処理を行い, FF 補償器と位置指令を最適化する。

図 9 に，GA による最適設計フローチャートを示す。初 期集団として $M$ 個体の解候補を生成後, 各世代では以下 の手順に従い遺伝的処理を行う。

(1) 最適化される設計パラメータは, 15 bit のバイナリで 表現された $\zeta_{f}, \zeta_{n}, \zeta_{d}, f_{f}, f_{n}, f_{d}, T_{m}$ ，ならびに 9 桁のグレイコードで表現された $T_{p}$ の計 8 パラメータ である。

（2）ボールねじ中央，遠端，近端の 3 つのテーブル初期位 


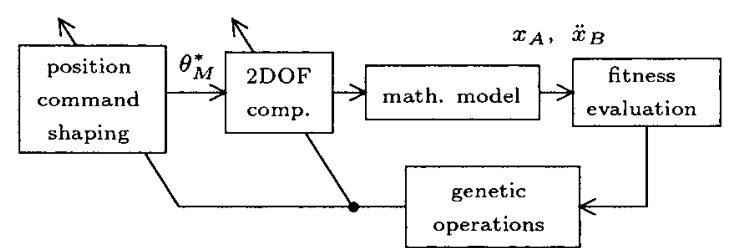

図 $8 \mathrm{GA}$ による FF 補償器と位置指令の最適設 計処理概要

Fig. 8. Conceptual diagram of optimal design of feedforward comp. and position command shape.

(1)

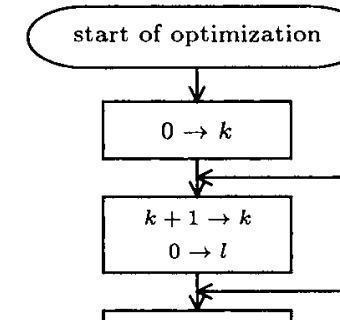

feedfoward compensator and position command design

(2)

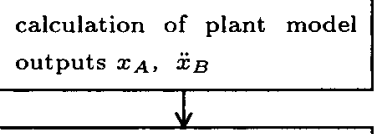

(3)

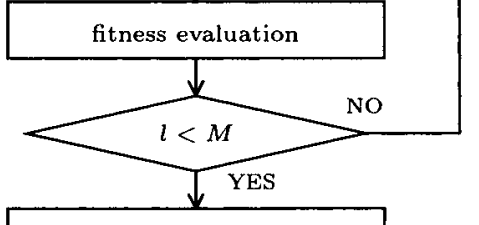

(4)

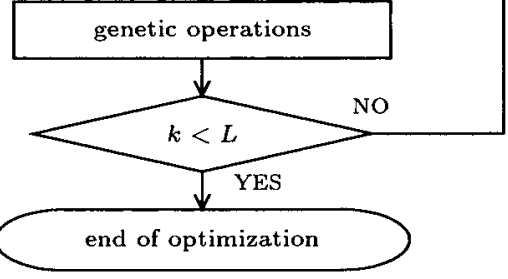

図 9 フィードフォワード補償器と位置指令の最 適設計処理フローチャート

Fig. 9. Flowchart of optimization process of feedforward comp. and position command shape.

置条件と，無負荷，負荷重量最大の 2 つの負荷重量条 件に対する計 6 つの駆動条件のもとで, 図 3 の 2 自由 度位置決め制御系に变形正弦力么曲線に基づく位置指 令を与えて,$x_{A}$ と $\ddot{x}_{B}$ の時系列データを計算する。

(3) $x_{A}$ の時系列データに対する整定時間およびオーバシ ユートの評価と， $\ddot{x}_{B}$ の時系列データに対する機台振 動の評価を実施して評価値 $F_{f i t}$ を導出する。

（4）選択，交叉, 突然変異, エリート保存からなる遺伝的 処理により，次世代の解候補を $M$ 個体生成する。

以上の処理を $L$ 世代繰り返し，最終的に最も良い評価を得 た解候補を最適化された FF 補償器と位置指令とする。な

\section{表 1 設計パラメータの探索範囲}

Table 1. Search range of free parameters.

\begin{tabular}{|cl|c|c|}
\hline parameter & & $\min$. & $\max$. \\
\hline$\zeta_{d}, \zeta_{n}, \zeta_{f}$ & & 0 & 1 \\
$f_{d}, f_{n}$ & {$[\mathrm{~Hz}]$} & 23.2 & 34.8 \\
$f_{f}$ & {$[\mathrm{~Hz}]$} & 1 & 500 \\
$N_{p}$ & & 0 & $2^{9}-1$ \\
$T_{m}$ & & 0 & 0.5 \\
\hline
\end{tabular}

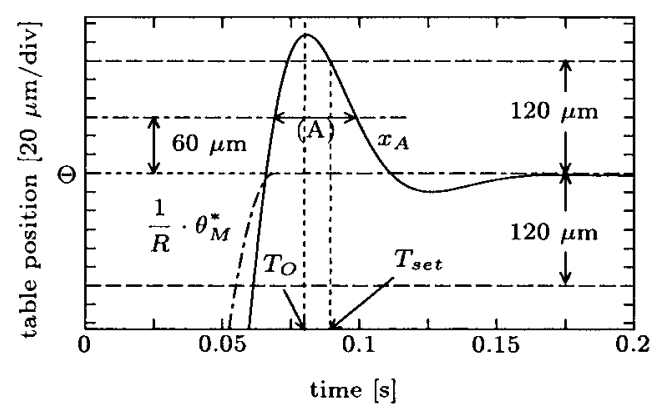

図 10 評価值導出時のテーブル位置応答波形

Fig. 10. Table position waveform in fitness evaluation.

お，GA の諸元は個体数 $M$ を 30 , 戦略方式をトーナメン 卜方式 (エリート保存 1 個体), 多点交叉 (染色体毎に一点 交叉, 交叉確率 0.9), 突然変異 (突然変異確率 0.03) とし, 進化世代数 $L$ を 50 とした。

表 1 に , 各パラメータの探索範囲を示す。 $f_{f}$ の探索範囲 の上限は, 本システムのサーボ帯域が $100 \mathrm{~Hz}$ 近辺である ことを念頭に十分に広い探索範囲となるよう決定した。ま た，機台振動周波数 $29 \mathrm{~Hz}$ 付近での最適解探索を目的に， $f_{d}, f_{n}$ の探索範囲は $29 \mathrm{~Hz}$ の $\pm 20 \%$ とした。移動時間 $T_{p}$ は, 9 桁のグレイコードを 10 進数に変換した値 $N_{p}$ に, 位 置制御サンプリング時間 $T_{S}(=0.5 \mathrm{~ms})$ を乗じて求める。

〈3.5〉 評価関数 評価值計算に用いるテーブル位置 応答波形の時系列データ $x_{A}[n]$, 及び機台加速度波形の時 系列データ $\ddot{x}_{B}[n]$ は，位置制御サンプリング時間 $T_{S}$ の下， 計算機上に構成したシステム数学モデルに対する計算機シ ミュレーションにより算出した。ここで,$n$ は $T_{S}$ のサン プル番号， $N_{S}$ は時系列データのサンプル総数である。

図 10 はテーブル位置応答波形の一例であり，2 本の水平 鎖線は目標位置 $\Theta$ に対する $\pm 120 \mu \mathrm{m}$ の要求位置決め仕樣 を， $T_{O}$ は目標整定時間を示す。

オーバシュートに対する評価では, $x_{A}[n]$ が目標位置に 対して $60 \mu \mathrm{m}$ 以上のオーバシュートを生じる (A) の区間 で (5) 式の評価関数を導入し, テーブル位置の目標位置へ の速やかな到達を図る。

$$
\begin{aligned}
& F_{A}=\sum_{n=0}^{N_{S}} W_{A}^{\prime}\left\{x_{A}[n]-\left(\Theta+60 \times 10^{-6}\right)\right\} \cdots(5) \\
& \text { ただし }, W_{A}^{\prime}= \begin{cases}0 & \left(x_{A}[n] \leq \Theta+60 \times 10^{-6}\right) \\
W_{A} & \left(x_{A}[n]>\Theta+60 \times 10^{-6}\right)\end{cases}
\end{aligned}
$$

整定時間に対する評価では, $x_{A}[n]$ が図 10 中の 2 本の水 

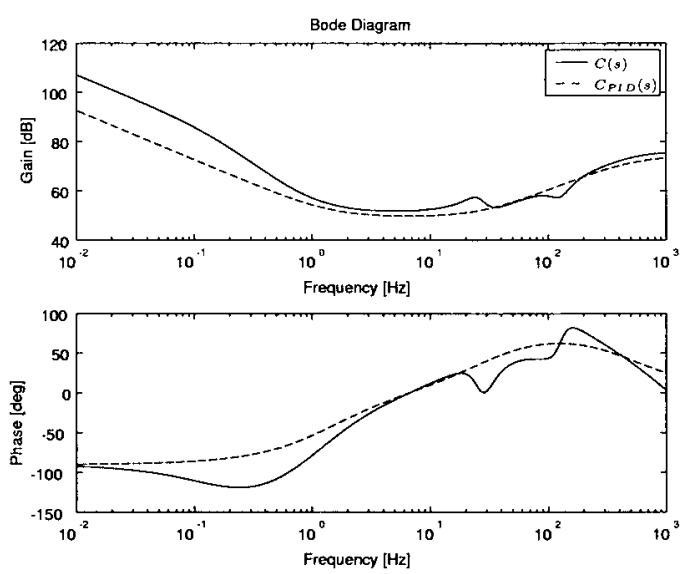

図 $11 H_{\infty}$ 補償器のボード線図

Fig. 11. Bode characteristics of $H_{\infty}$ compensator.

平鎖線内に整定完了した時間 $T_{s e t}$ が目標整定時間 $T_{O}$ を満 足するか否かを判断し，位置決め整定時間に対するペナル ティとして次式の評価を行う。

$$
F_{B}= \begin{cases}0 & \left(T_{\text {set }} \leq T_{O}\right) \\ W_{B} & \left(T_{\text {set }}>T_{O}\right)\end{cases}
$$

一方，機台振動抑制を目的とした評価を実施するため，次 式に示す評価区間全域の機台加速度波形の絶対値積分を計 算する。

$$
F_{C}=\sum_{n=0}^{N_{S}} W_{C}\left|\ddot{x}_{B}[n]\right|
$$

以上の評価関数 $F_{A}, F_{B}, F_{C}$ を，テーブル位置と負荷 重量に応じた 6 通りの駆動条件下で光れ計算し，兰れ らを全て加算することでGA の評価値 $F_{f i t}$ とする。

評価関数中で用いた各パラメータは, $\Theta=17.4 \times 10^{-3} \mathrm{~m}$ ， $T_{O}=80 \times 10^{-3} \mathrm{~s}, N_{S}=400, W_{A}=5 \times 10^{6}, W_{B}=10^{4}$, $W_{C}=1$ である。この場合，最終世代での最小評価值は 200 程度であるので, 目標整定時間を満足しない解候補が同世 代中のエリート解となることを防ぐため，200に対して十 分大きい $F_{B}$ となるよう， $W_{B}$ を決定した。

\section{2 自由度位置決め制御系設計結果}

〈 4 1 1 FB 補償器設計結果 第 $\langle 3 \cdot 1\rangle$ 項の一般化プラ ントと重み関数の条件の下, Matlab による $H_{\infty}$ 補償器設計 を行い, 図 11 中の実線で示す $C(s)$ を得た ${ }^{(14)}$ 。ここで, 図 中の破線で示される同等なゲイン特性を有する PID 補償器 $C_{P I D}(s)$ を設計し特性比較を行った。光の結果， $C_{P I D}(s)$ に比して $C(s)$ は位相余有を最大 $19.65^{\circ}$ ，ゲイン余有を最 大 $3.48 \mathrm{~dB}$ 増加できている。さらに, 前述のテーブル初期 位置と負荷重量に対する全ての駆動条件において， $C(s)$ は $10.58^{\circ}$ 以上の位相余有と $4.64 \mathrm{~dB}$ 以上のゲイン余有を実現 できている。従って，パラメータ変動に対する必要最低限 な安定余有の確保による，ロバスト安定性を備えた FB 補 償器が設計されている。
表 210 回の試行に対する $\mathrm{FF}$ 補償器と位置指令 の最適設計結果

Table 2. Final fitness $F_{f i t}$ and optimal design results in each trial.

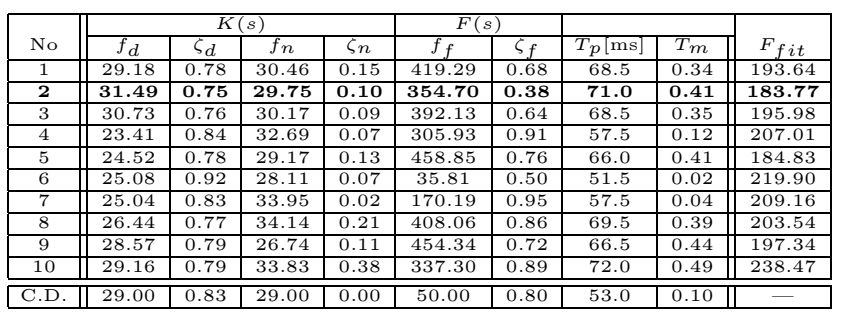

〈4 2〉 FF 補償器と位置指令の最適設計結果 GA に よる $\mathrm{FF}$ 補償器と位置指令の最適設計処理を 10 回試行した 場合の最終評価値 $F_{f i t}$ と $F(s), K(s), T_{p}, T_{m}$ の設計結 果を表 2 に示す。また，本最適化結果の比較評価を目的に， 従来法として設計したパラメータ (Conventional Design ：C.D.）を併せて示す。ここで, 従来手法では，加速から 減速までの変化が滑らかな位置指令を実現するため $T_{m}$ を 0.1 とし，位置指令の高周波成分除去を目的に, $F(s)$ のカッ トオフ周波数は $50 \mathrm{~Hz}$ としている。ただし， $F(s)$ の影響に よって制御系に位相遅れが生ずるため，位置指令の移動時 間 $T_{p}$ は $53 \mathrm{~ms}$ としている。

一方，GA による最適設計では，最終評価值が最も小さ い試行 No.2 の場合， $T_{m}=0.41$ と設計された結果，位置 指令の高周波成分が低減され， $F(s)$ のカットオフ周波数は 位置決め制御系のサーボ帯域に比べて十分高い $354.7 \mathrm{~Hz}$ と 最適化されている。弚の結果， $F(s)$ の位相遅れに対する影 響か緩和され， $T_{p}$ は $71 \mathrm{~ms}$ となって位置指令の加速ピーク 值を減少できている。

従来設計法と GA による最適設計法による位置指令の特 性をみるため，位置指令を 2 階微分して得られる加速度波 形を图 12 に，弚の振幅スペクトルを図 13 に示す。図 12 中，破線で示す従来設計に比へてて，実線で示す最適設計では 位置指令の移動時間が $18 \mathrm{~ms}$ 延び，乥れに伴い加速度波形 のピーク值が低減している。図 13 で, 従来設計に比べて， 最適設計では全周波数領域で振幅を低減できており，FF 補 償器と位置指令を連携させた最適設計により，システムに 与える電気的・機械的エネルギーを低減して機台振動を抑 制することが期待できる ${ }^{(15)}$ 。

〈 4. 3〉移動距離変化時の位置指令最適設計結果移動距 離の変化に対しては，FF 補償器は既に十分な目標值追従性能 と機台振動抑制性能を実現できているので，位置指令のみを $\mathrm{GA}$ により最適設計することとし, $32 \mathrm{~mm}$ と $48 \mathrm{~mm} の 2$ 種 類の移動距離に対して検討を行った。位置決め仕樣は, 目標 位置に対する $\pm 120 \mu \mathrm{m}$ の位置決め整定条件に対し , $32 \mathrm{~mm}$ 移動時は $109 \mathrm{~ms}$ 以内 , $48 \mathrm{~mm}$ 移動時は $134 \mathrm{~ms}$ 以内での整 定である。評価関数には (5),(6),(7) 式を用いるが,移動距 離 $32 \mathrm{~mm}$ の場合に $\Theta=32 \times 10^{-3} \mathrm{~m}, T_{O}=109 \times 10^{-3} \mathrm{~s}$ を 与え , $48 \mathrm{~mm}$ の場合に $\Theta=48 \times 10^{-3} \mathrm{~m}, T_{O}=134 \times 10^{-3} \mathrm{~s}$ を与える。この場合, 設計パラメータは 2 つなので, 解空 


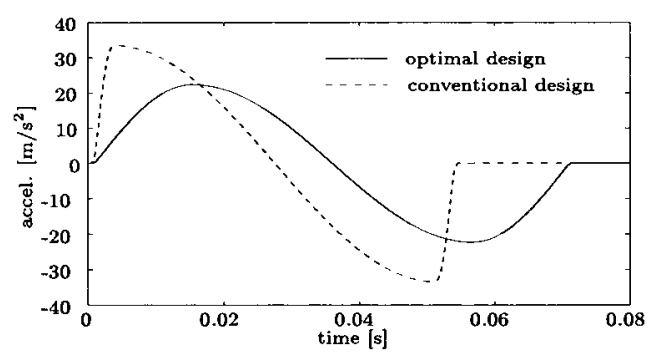

図 12 位置指令の 2 階微分の加速度波形

Fig. 12. Acceleration waveforms of position command.

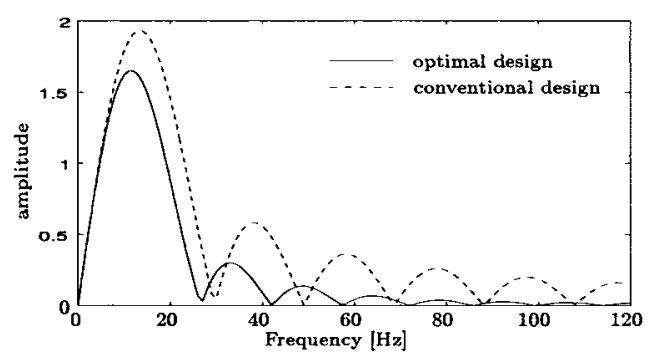

図 13 加速度波形の振幅スペクトル

Fig. 13. Amplitude spectrum of acceleration waveforms.

間は複雑ではないと判断して GA の進化世代数を 30 とし た。光の結果， $32 \mathrm{~mm}$ 移動時は $T_{P}=101.5 \mathrm{~ms}, T_{m}=0.46$, $48 \mathrm{~mm}$ 移動時は $T_{P}=128 \mathrm{~ms}, T_{m}=0.45$ と最適化された。

\section{5. 位置決め制御実験の結果と検証}

移動距離 $17.4 \mathrm{~mm}$ 時の最適設計結果である表 2 の No.2 に対し，位置決め制御性能と機台振動抑制効果をみるため実 験を行った。図 14 は, 負荷重量最大でテーブル位置がボー ルねじ中央時の結果であり，図中，実線は GA による最適 設計の場合，破線は従来設計の場合を示す。なお，以降の位 置決め応答波形同樣，図 (a) 中の 2 本の水平一点鎖線は位

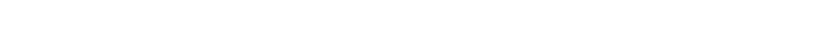
示す。図 (a)から，従来設計に比べて最適設計ではオーバ シュートに約 $14 \mu \mathrm{m}$ の増加が見られるが, 位置決め整定後 の残留振動の少ない位置決めが実現できている。図 (b) か ら，従来設計に比へて最適設計では，加速及び減速時にお ける機台加速度のピーク值を低減でき，特に位置指令開始 後約 $60 \mathrm{~ms}$ 経過時点において，従来設計での $-0.68 \mathrm{~m} / \mathrm{s}^{2}$ に比べて最適設計では $-0.47 \mathrm{~m} / \mathrm{s}^{2}$ に低減できている。

テーブル位置変化に対するロバスト性能を検証するため， 負荷重量最大時にテーブル初期位置を変化させた場合の応 答波形を図 15 に示す。図中，実線はテーブル初期位置が ボールねじ遠端の場合，破線は近端の場合である。图 (a) から，遠端の場合は岡性の低下に伴うねじれ振動振幅の増 加が顕著になるが，いずれの場合も要求制御仕樣を満足す る位置決めか実現できている。また，図 (b) から，図 14(b) 中実線のボールねじ中央時と同樣, 最大振幅を $0.5 \mathrm{~m} / \mathrm{s}^{2}$ 程 度に抑えた機台振動抑制が実現できている。

図 16 と図 17 は,移動距離を $32,48 \mathrm{~mm}$ として兰れ光れ

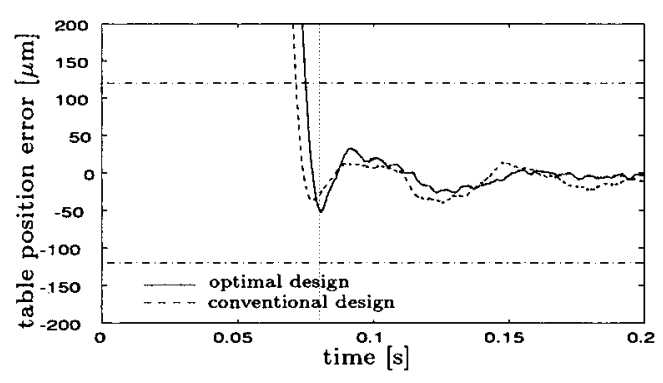

(a) Waveforms of table position error

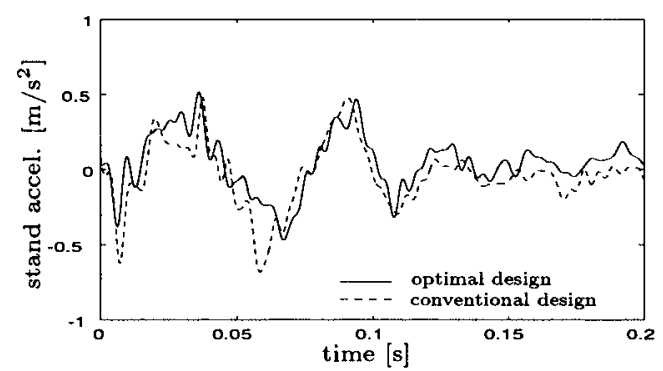

(b) Waveforms of stand accel.

図 14 実機応答波形 (負荷重量最大, テーブル 初期位置中央時)

Fig. 14. Response waveforms of table position error and stand acceleration.

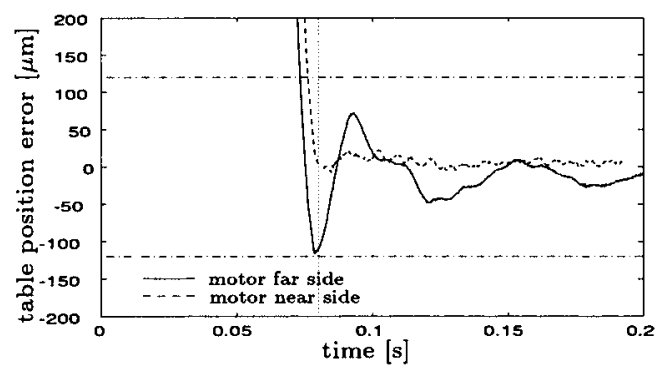

(a) Waveforms of table position error

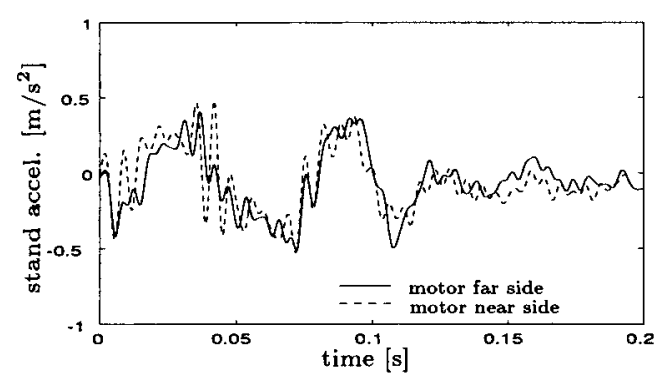

(b) Waveforms of stand accel.

図 15 ボールねじ遠端/近端での実機応答波形

Fig. 15. Response waveforms of table position error and stand acceleration at motor far/near side.

最適化された位置指令を用いた場合の応答波形である。こ こで, 負荷重量は最大で, テーブル初期位置はボールねじ 中央である。いずれの場合も目標制御仕樣を満足し, 残留 振動の少ない良好な位置決め制御性能を実現している。 


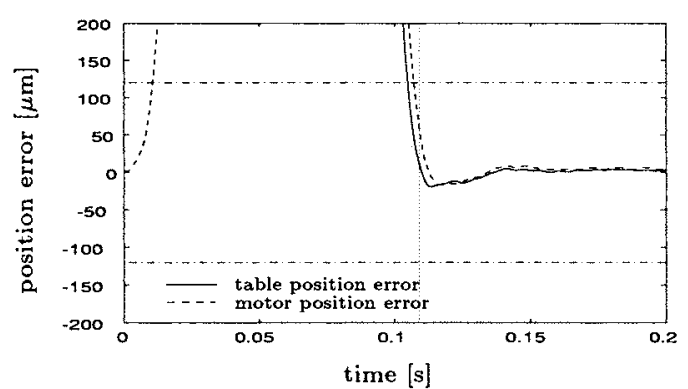

(a) Position error waveforms of table and motor

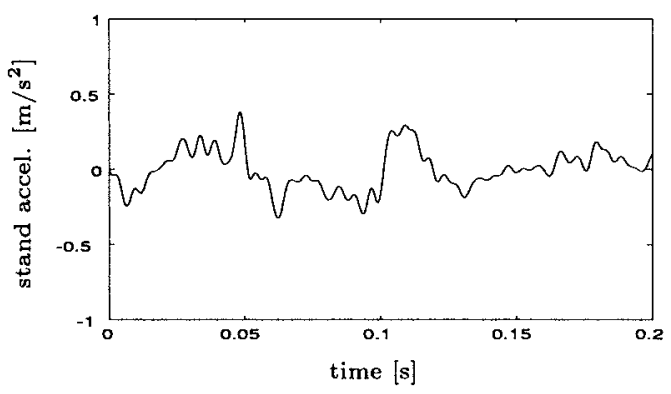

(b) Waveform of stand accel.

図 16 移動距離 $32 \mathrm{~mm}$ 時の実機応答波形

Fig. 16. Experimental results (movement of $32 \mathrm{~mm}$ ).



(a) Position error waveforms of table and motor

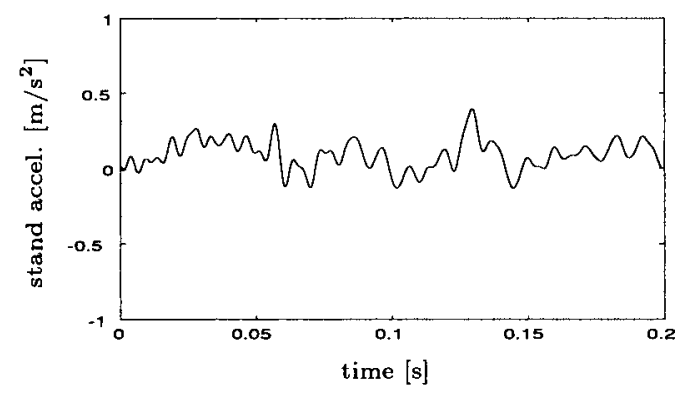

(b) Waveform of stand accel.

図 17 移動距離 $48 \mathrm{~mm}$ 時の実機応答波形

Fig. 17. Experimental results (movement of $48 \mathrm{~mm}$ ).

機台振動抑制効果を定量的に示すため，機台加速度波形 の $5 \mathrm{~Hz}$ から $100 \mathrm{~Hz}$ までのパワースペクトル密度の総和を 表 3 に示す。表中のデータは順に , 移動距離 $17.4 \mathrm{~mm}$ に対 する，テーブル初期位置がボールねじ中央で無負荷及び負 荷重量最大の場合，負荷重量最大で初期位置が近端及び遠端 の場合，移動距離 $32 \mathrm{~mm}, 48 \mathrm{~mm}$ に対する，負荷重量が最
表 3 機台加速度波形に対するパワースペクトル 密度の総和

Table 3. Summing integration of power spectrum density for stand acceleration.

\begin{tabular}{|l|c|c|}
\hline & conventional design & optimal design \\
\hline movement of $17.4 \mathrm{~mm}$ & & \\
\hline middle (without load) & 1.027 & 0.3617 \\
\hline middle (with load) & 8.427 & 6.450 \\
\hline motor near side & 7.022 & 5.956 \\
\hline motor far side & 11.16 & 7.289 \\
\hline \hline movement of $32 \mathrm{~mm}$ & 3.368 & 3.434 \\
\hline movement of $48 \mathrm{~mm}$ & 2.309 & 1.845 \\
\hline
\end{tabular}

大でテーブル初期位置がボールねじ中央の場合である。提 案の最適設計では, 従来設計に比して負荷重量やテーブル 初期位置によらず機台振動のパワースペクトル密度の総和 を低減できている。特に，移動距離 $17.4 \mathrm{~mm}$ でテーブル位 置がボールねじ中央の場合，無負荷時で約 $65 \%$, 最大負荷 時で約 $23 \%$ 低減できている。移動距離の変化に対しては， $32 \mathrm{~mm}$ の場合では両者に大差はないものの，48 mm の場 合には $20 \%$ 程度の低減が実現されている。この結果 , 移動 距離の変化に対して, FF 補償器を変更することなく，位 置指令の最適設計のみで所望の位置決め制御性能と機台振 動抑制性能を実現できることが検証された。

\section{6. あとがき}

本論文では，機台上に設置されたボールねじ駆動テーブ ルシステムを対象に，機台振動抑制と高速 ·高精度位置決 めを目的とした， GA による FF 補償器と位置指令の同時 最適設計法を提案した。本研究で得られた成果は, 以下の ように要約できる。

（1）テーブル位置や負荷重量の変化に対するシステムのロ バスト安定化を実現する $H_{\infty}$ 補償器をフィードバック 系に有する 2 自由度制御系を前提に, FF 補償器及び 变形正弦力ム曲線に基づく位置指令の設計パラメータ を GA によって自律設計する手法を提案した。

(2) GA による最適化評価では, 複数のテーブル駆動条件 下でのテーブル位置応答波形並びに機台加速度波形を 同時に評価することで, 駆動条件変化にロバストな設 計パラメータの最適化を目指した。

(3) テーブル移動距離の变化に対しては, $\mathrm{FF}$ 補償器は光 のままに位置指令の設計パラメータのみを最適化する ことで対処し，最適化計算負荷の軽減を図った。

（4）供試テーブル駆動システムによる実験検証では，全て の駆動条件下で所望の位置決め整定精度を満足し，か つ機台振動も従来設計手法に比して最大 $65 \%$ の低減を 実現でき，優れた機台振動抑制能力を有する高速・高 精度位置決め制御系の実現をみた。

今後は,フィードバック補償器に対する最適設計も試み, 、 バスト制御性能や外乱抑制能力の更なる向上を目指したい。 (平成 15 年 7 月 25 日受付, 平成 15 年 11 月 13 日再受付) 


\section{文献}

(1) H. Zidan, T. Tsuji, S. Hao, and R. Oguro: "Feedforward Control Design for Vibration of Machine Stand", T. IEE Japan, Vol.120-D, No.3, pp.404-409 (2000-3) (in Japanese) ハサン ジダン・过 輝生・Shuang-Hui Hao・小黑龍一 : $\ulcorner$ Feedforward 制御による機台振重抑制制御」, 電学論 D, 120, 3, pp.404-409 (2000-3)

( 2 ) F. Ohkawa, H. Honda, J. Kobayashi, K. Kuboyama, and R. Oguro: "Robust Model Following Control of a Feed Drive System Hindered by a Machine Stand Vibration", T. JSME (C), Vol.68, No.668, pp.101-106 (2002) (in Japanese) 大川不二夫・本田英己 ·小林 順・久保山幸司・小黑龍一 : 「ロバ ストなモデル追従制御による機台振動系の振動抑制」，機論 C, 68, 668, pp.101-106 (2002)

（3）前田 肇・杉江俊治：アドバンスト制御のためのシステム制御理論, 朝倉書店 $(1990)$

(4) S. Morimoto, M. Ohashi, and Y. Takeda: "Speed Control of Two-mass System Based on $H^{\infty}$ Control Theory", $T$. IEE Japan, Vol.114-C, No.11, pp.1109-1115 (1994-11) (in Japanese)

森本茂雄 $\cdot$ 大橋真和 $\cdot$ 武田洋次 : $\left\ulcorner 2\right.$ 慣性共振系の速度制御への $H^{\infty}$ 制御理論の適用」, 電学論 C, 114, 11, pp.1109-1115 (1994-11)

( 5 ) M. Iwasaki and N. Matsui: "Optimal Command Shaping for Vibration Suppression in Robot Arm Motion", T. IEE Japan, Vol.117-C, No.1, pp.50-56 (1997-1) (in Japanese) 岩崎 誠・松井信行：「振動抑制効果を考慮したロボットアームの 最適位置指令設計法」, 電学論 C, 117, 1, pp.50-56 (1997-1)

(6) M. Hirata, T. Hasegawa, and K. Nonami: "Seek Control of hard Disk Drives Based on Final-State Control Taking Account of the Frequency Components and the Magnitude of Control Input", Proc. of 7th International Workshop on Advanced Motion Control, pp.40-45 (2002)

( 7 ) S. Hara, K. Wakamatsu, and T. Narikiyo: "Simulation-Based Reference Design and Its Application to Positioning Control of Vibration Systems", T. JSME (C), Vol.68, No.672, pp.2532 (2002) (in Japanese)

原進・若松康介・成清辰生 : 「シミュレーションベースによる 目標軌道設計と炎の振動系の位置決め制御への適用」, 機論 C, 68, 672, pp.25-32 (2002)

（8）北野宏明：遺伝的アルゴリズム, 産業図書 (1993)

(9) K. Ito, R. Nagata, M. Iwasaki, and N. Matsui: "GA-Based Autonomous Design of Robust Fast-Response and HighPrecision Positioning Controller Considering Machine Stand Vibration Suppression", IEEJ Technical Meeting on Industrial instrumentation and control, IIC-03-25, pp.57-62 (2003) (in Japanese)

伊藤和晃・永田 良・岩崎 誠・松井信行: 「機台振動抑制を考慮し た GA によるロバスト高速・高精度位置決め制御系設計」, 電気学 会産業計測制御研資, Vol.IIC-03-25, pp.57-62 (2003)

(10) M. Iwasaki, N. Tsumagi, H. Hirai, and N. Matsui: "Genetic Algorithm-Based Autonomous Design of Weighting Functions for $H_{\infty}$ Compensator", T. IEE Japan, Vol.121-D, No.12, pp.1235-1242 (2001-12) (in Japanese)

岩崎 誠・妻木宣明・平井洋武・松井信行 : $\left\ulcorner H_{\infty}\right.$ 補償器設計にお ける遺伝的アルゴリズムを用いた重み関数の自律生成」, 電学論 D, 121, 12, pp.1235-1242 (2001-12)

(11) M. Iwasaki, K. Sakai, and N. Matsui: "Genetic AlgorithmsBased Design of Vibration Suppression Compensator for 2Mass Resonant System", T. IEE Japan, Vol.120-D, No.3, pp.351-358 (2000-3) (in Japanese)

岩崎 誠・酒井岡司・松井信行 :「遺伝的アルゴリズムによる 2 慣 性共振振動系の制振補償器設計」, 電学論 D, 120, 3, pp.351-358 (2000-3)

(12) K. Ito, M. Iwasaki, and N. Matsui: "GA-Based Autonomous Feedforward Compensator Design for Robust Fast-Response and High-Precision Positioning", J. JSPE, Vol.69, No.1, pp.58-63 (2003-1) (in Japanese)

伊藤和晃・岩崎 誠・松井信行 : 「ロバスト高速 ·高精度位置決め 制御のための GA によるフィードフォワード補償器自律設計」, 精 密工学会誌, 69, 1, pp.58-63 (2003-1)

(13) 山口 稔・佐井秀範・村田 誠・牧野 洋・浜谷 徹:「ベルトコン ベアの運動特性に関する研究 (第 1 報) 一システムと光の制御—」, 1989 年度精密工学会秋季大会学術講演会論文集, pp.79-80 (1989)

(14) 野波健蔵 編, 西村秀和・平田光男共著：MATLAB による制御系
設計, 東京電機大学出版局 $(1998)$

(15) 井上善雄ほか：振動の考え方・とらえ方, オーム社 (1998)

伊藤 和 晃 (正員) 1975 年 5 月 20 日生。 2003 年 3 月名古

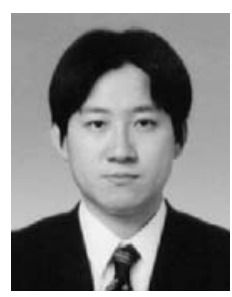
屋工業大学大学院工学研究科博士後期課程修了。 同年 4 月，豊田工業高等専門学校電気・電子シス テム工学科助手, 現在に至る。工学博士。主に, メカトロニクス機器の振動抑制制御に関する研究 に従事。精密工学会, IEEE 会員。

永田良 (学生員) 1978 年 10 月 11 日生。 2003 年 3 月

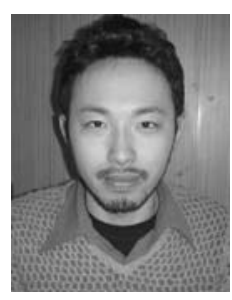
名古屋工業大学大学院工学研究科博士前期課程修 了。在学中はメカトロニクス機器の振動抑制制御 系の設計に関する研究に従事。

岩 崎

誠 (正員) 1964 年 1 月 15 日生。1991 年 3 月名古

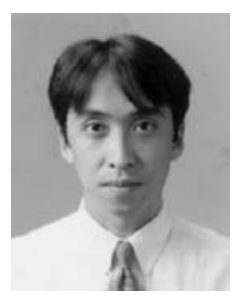
屋工業大学大学院工学研究科博士後期課程修了。 同年 4 月，名古屋工業大学電気情報工学科助手， 2000 年 4 月, 助教授, 現在に至る。1997 年 10 月〜1998 年 3 月まで文部省在外研究員としてド イツ連邦共和国ケムニッツ工科大学, 同ミュンヘ ン工科大学に派遣, 2002 年 9 月〜 2003 年 7 月ま で文部科学省在外研究員としてドイツ連邦共和国 ケムニッツ工科大学に派遣。工学博士。運動制御の研究に従事。精密 工学会, 計測自動制御学会, IEEE 会員。

松井信 行 (正員) 1943 年 5 月 7 日生。1968 年 3 月名古


屋工業大学大学院修士課程修了。同年 4 月, 名古 屋工業大学助手, 講師, 助教授を経て, 1985 年 4 月，電気情報工学科教授， 2000 年 4 月 2002 年 10 月まで同大学副学長, 同年 11 月に教授に復職 後, 2004 年 1 月, 同大学学長, 現在に至る。工 学博士。パワーエレクトロニクスおよびモーショ ンコントロールの研究と教育に従事。2001 年電 気学会部門活動功労賞, 2002 年電気学会学術振興賞 (論文賞), 同優 秀技術活動賞, 同産業応用特別賞 (貢献賞), 小平記念賞, IEEE/IES Best Paper Award 受賞。計測自動制御学会会員, IEEE Fellow。 